\title{
The evaluation and steering of English academy schools through inspection and examinations: national visions and local practices
}

\author{
Jaakko Kauko $^{\mathrm{a} \star}$ and Maija Salokangas ${ }^{\mathrm{b}}$ \\ ${ }^{\mathrm{a}}$ University of Helsinki, Finland; ${ }^{\mathrm{b}}$ Trinity College Dublin, Republic of Ireland
}

\begin{abstract}
The article analyses the redefinition and distribution of powers between central governance and local actors in English independent state-funded schooling. Earlier research on governance confirms the importance of the local and the school level in reshaping national-level reforms and steering policies. The research draws on data from interviews with national-level policymakers and an ethnographic school case study, thereby yielding contrasting views and perceptions of governance at the national level, and the day-to-day reality at the local level. The empirical analysis gives mixed results in that the national visions of innovative local practices seem not to be manifest at the local level. Despite the legal and financial freedoms granted to academy schools, the case academy is constrained by the national policy of steering by evaluation, namely inspection and testing, and the managerial practices of the sponsor. The article concludes that the real effect of academies is still under construction and meanwhile their space for action is strongly restricted by the tools of evaluation. As a more theoretical conclusion the analysis suggests that future analysis should concentrate more on action rather than structures and on evaluation as an embedded practice.
\end{abstract}

\section{Introduction}

Our research concerns the redefinition and re-distribution of powers between central governance and local actors in publicly funded education. Permutations of elements of school autonomy, market approaches and varying local-authority positions have resulted in different outcomes in European contexts. A decentralising policy enhancing school autonomy has boosted competition, hierarchies and differentiation among schools and classes in Austria, for instance, with a strong hybridisation of the old and the new (Altrichter et al., 2014). In the case of Sweden, liberalised school choice and the markets of education provision as part of the Free School programme have led in Stockholm to segregation on the grounds not only of ability but also of ethnicity (Söderström \& Uusitalo, 2010). Decentralisation and strong municipal autonomy have constituted one factor in buffering against transnational flows of evaluation practices in Finland (Simola et al., 2013), whereas in England

\footnotetext{
ॠCorresponding author. Jaakko Kauko, Research Unit focusing on the Sociology and Politics of Education (KUPOLI), Institute of Behavioural Sciences, PO Box 9, FI-00014 University of Helsinki, Finland. Email: jaakko.kauko@helsinki.fi
} 
there are indications of disruptive effects of reforms on public service (Andrews \& Boyne, 2012). Common to all of these developments is their inherent embeddedness in local contexts. Indeed, the notions of schools changing reforms rather than reforms changing schools (Tyack \& Cuban, 1995), and of travelling policies adapting to embedded policies (Ozga \& Jones, 2006), have been thoroughly studied in earlier research on educational governance. As Ozga and Jones (2006, p. 6) point out, although 'policy choices may be narrowing, national and local assumptions and practices remain significant'. There is also evidence that this local-level path dependency ('increasing returns', see Pierson, 2000) cannot explain situations of strong external intervention (Gains et al., 2005). The policy on introducing academy schools in England could be considered a radical intervention, and we set out to analyse how this has affected local-level actors.

On the one hand, the English education system is considered rather highly centralised (Ainley, 2001) compared with its European counterparts, but on the other hand many reforms have aimed at dismantling bureaucratic hierarchical structures. Much of the dismantling has happened through the general administrative-doctrinal change in what Hood and Jackson (1991) identified as new public management (NPM), which could be crystallised as the introduction of private-sector methods in the public sector, and the outsourcing of public-sector functions to the private sector (e.g. Osborne \& Gaebler, 1993). In general, the NPM reforms in education aim to support autonomy in schools, dismantle the hierarchies of the classic bureaucratic organisation and at the same time enhance the managerial capacity of head teachers (Jarl et al., 2012, pp. 431-432). This development is evident within the 'competition state' (Ball, 2013) in the emerging sector of state-funded independent schools, academies and free schools.

English schools are considered to operate in an environment moulded by NPM reforms, but which has been further shaped by the idea of networked governance (Ball \& Junemann, 2012). Currently there are elements of both governance types in English education provision. In Stoker's terms, the difference is that whereas the NPM model is based on consumer choice, networked community governance draws on complex processes of interaction (Stoker, 2011, p. 18). Summing up earlier literature, Pollitt (2009) suggests that the main feature of public-service networks is that they are self-organising, although they frequently require an external stimulus. This type of 'post-welfare society' (Tomlinson, 2001) relies on long-term consensual neoliberal networks in a pluralistic and complex setting (Olmedo, 2014). According to this interpretation, the remaining coherence in education seems to be the use of data in governance that recreates the system in a web of processes and actors as opposed to unitary stories or common myths (Lawn, 2013, pp. 237-239). As Maroy and Van Zanten (2009) suggest, relations in the English setting could be described as 'multiregulation' in which schools have 'competitive interdependence'. The notions of NPM and networked governance both aptly describe the current changes and challenges in education governance, the former underpinning the reforming structures and the latter referring to the new ways of steering. Our entry point in understanding the shifts in governance is independent state-funded education and, in particular, the relatively new type of school, the academy, which helps us to grasp both the restructuring of education as well as the changes in steering. 
The rapidly developing independent sector of state-funded education in England has also caught the attention of other researchers. First of all, many are pointing out the overlapping ideology between the two main parties on the matter. Academies were first introduced in 2000 under the New Labour government as a remedy for persistent educational underperformance in urban areas. The coalition government embraced the programme and broadened its scope dramatically in 2010 by inviting all English primary and secondary schools to become academies (Department for Education, 2010). Goodman and Burton (2012) highlight the continuity of a movement away from state schooling since the 1988 Education Reform Act regardless of the party in power. Commenting on a similar trend, Exley and Ball (2011) note how Conservative ideas such as independent state-funded education were pushed forward during the New Labour era, although with a different nuance. Second, other researchers refer to failing political goals, or at least to complex outcomes. Aggregating earlier research, Hatcher (2011) concludes that free schools are unlikely to reach the two aims they set out: raising attainment and reducing inequality. In a quantitative analysis of Key Stage- 4 results, Gorard (2009) found no evidence that academies produced better results than the schools they replaced and, in his later analysis, showed how converted academies were established in areas segregated by socioeconomic status and thus contributed to sustaining the inequalities (Gorard, 2014). Concentrating on the central political argument of freedom for schools, Bamfield (2012) points out the connotation of freedom as independent self-governance rather than non-intervention by the state. Whereas the former could lead to 'autonomous schooling established on more genuinely democratic lines', the latter threatens to create 'a new set of fiefdoms' when government refrains from controlling the academy sponsors (Bamfield, 2012). Earlier research supports the supposition in our analysis of how the politically stable idea of independent state-funded schooling does not necessarily manifest at the local level. Related to the discrepancy between policy and practice, there is a paradoxical dual existence of a purported increase in school autonomy and a tight governmental grip through performance testing and targets (Exley \& Ball, 2011; Goodman \& Burton, 2012). Given the parallel existence of 'multi-regulation', NPM bureaucracy dismantling and increased intervention through state funding, we considered it important to focus our study on the governance tools of evaluation, and to analyse the extent to which the local level still matters in moulding the reforms.

According to Lundgren (1991) legislative, economic, ideological and evaluative dimensions form the arsenal of steering forces in policymaking. Legislative changes, in addition to fostering change in other steering forces, tend to alter the general structural framework within which schools operate. In the case of independent state-funded education, school autonomy has been buttressed through legislative and economic rearrangements throughout the course of history. Indeed, the general description of English education provision during the post-war period from 1944 until the 1970s was a national system run by local authorities. Within this framework central government had a right of veto, local government decided on resource allocation, and it was mainly up to the teachers to decide upon the curriculum and teaching methods (Briault, 1976). This set-up was questioned in the so-called Great Debate of the 1970s. A radical and concrete change was the 1988 Education Reform Act, which 
began to take effect more dramatically during the 1990s when local-central relationships were reformed in a centralist manner through the introduction of market approaches, and as the National Curriculum challenged the teachers' control over taught content and methods (Evans \& Penney, 1994; Clarke \& Newman, 1997; Tomlinson, 2001; Ball, 2013). The state-funded academies enjoy more freedom in this centralised but heavily marketised environment, as they are granted exemptions from following the curriculum and complying with agreements on teachers' pay and conditions, as well as having more budgetary independence. This autonomy is one of the cornerstones of the managerial project in that it is understood to create conditions for innovation and thus to enhance learning outcomes (e.g. Department for Education, 2013a, b). The capacity of the academies to introduce innovations (Gunter \& McGinity, 2014) and the New Labour vision of using third-sector bodies (Kelly, 2007) have been criticised for being more ideological than well-functioning solutions for public administration. Indeed, the change to academies could be seen as an ideological solution that fits in well with the current landscape of English education policy even after the New Labour government. However, ideological steering is not the focus of our research: in analysing evaluation we rather scrutinise the differences between national-level policy vision and local-level practice.

Of the four steering forces, the legal and the financial frameworks set by the state have different effects on the different school types. Our focus here is exclusively on academies, and more specifically sponsored academies, a type of school that enjoys a certain amount of freedom in these matters. We are interested in the possible effects of evaluation on these academies. Evaluation in education covers a wide array of activities on multiple levels ranging from student assessments and school inspections to national-curriculum evaluation and international comparisons (Kellaghan et al., 2003). It could be argued that the overarching feature of evaluation is the soft power, steering with the help of comparing and collating data (Grek et al., 2009). According to our understanding, soft power such as evaluation is something that redefines different actors' understandings of desirable action through setting explicit targets. Dahler-Larsen (2012, p. 173), for instance, describes the effects as 'constitutive', meaning how 'tests, measurements and indicators help define the social realities of which they are a part'. We argue here that in the English context of education, evaluation has become all the more powerful through the process of primarily legal but also to some extent financial deregulation. We use the term evaluation in this article only in the narrow meaning of inspection and standardised testing, and analyse their effect on the formal promotion of school autonomy. We thereby shed light on the policy on academies from the perspectives of both policymaking and practice.

\section{The research data and questions of access}

The research data comprise interviews with key policymakers and officials, and ethnographic research over a two-year period. The data collection and the initial analysis were conducted independently in the context of two different research projects, the ethnographic case study from an academy (Salokangas, 2013) and the interviews with policymakers. The aim of the ethnographic observation was to assess the implications 
of the policy in a case academy with regard to its relations with the sponsor, the local authority and central government. Salokangas was embedded (McGinity \& Salokangas, 2014) for two academic years (2010/11 and 2011/12) in the case academy, sponsored by a multi-academy sponsor that, at the time of the data collection, managed a chain of more than 15 academies. The ethnographic data utilised in this article encompasses interview, observation as well as documentary data from the academy and the sponsor. Kauko carried out 13 interviews alone or together with Jenny Ozga during 2013. The informants included six politicians (two Labour, two Conservative, one cross-bench and one Liberal Democrat), two national-level and one local-level official, and four stakeholders from a trade union, a Regional Inspection Service Provider, a religious community and a national newspaper. Among the interviewees were three former Her Majesty's Chief Inspectors of Schools in England, two former Secretaries of State for Education and two who were involved in organisations that sponsored academies. The interviewed officials were not currently working in government or local administration. The interviews focused on the relations between different actors in education politics, and on what the interviewees considered the most important national and international reforms and processes. In order to ensure anonymity the politicians are referred to in three groups (Labour, Conservative, other), and officials and stakeholders each as one group.

Both methods of data acquisition for the purposes of this article raise the question of access in terms of the quality of the data, the validity of the results and ethics. Salokangas was embedded in the academy, which enabled her to participate in its day-to-day life for a prolonged period of time in order to conduct participant observations for her $\mathrm{PhD}$ thesis (Salokangas, 2013). The research was conducted under a three-year PhD studentship arrangement between the case academy and the School of Education, University of Manchester (Salokangas, 2013). Her involvement in the academy began in September 2010 and she was present in the school during term time on a weekly basis until June 2012 . The data presented were gathered during the academic year 2011/12. The embedded research arrangement facilitated observation from a close distance of the day-to-day life of the academy and the decision-making of the academy leadership team and the chainlevel governance. It also gave access to the academy and its sponsorship policy that was not available to the wider public. As such, the research arrangement provided her with privileged access, which has eluded many field researchers (Walford, 1987), and has been reported as being specifically problematic for researchers studying sponsored academies to obtain (Woods \& Woods, 2009).

Three main sets of guidelines and procedures were followed to ensure that the research was conducted ethically: the ethical guidelines of the British Educational Research Association (2004) and the University of Manchester were complied with, and a research contract was drawn up to ascertain that the three parties involvedthe researcher, the academy and the University — had a similar understanding of the terms and conditions of the research in terms of participant anonymity and academic integrity, for example (Salokangas, 2013). Finally, in order to make sure that a variety of voices would be heard and appropriately interpreted, the collected data was validated by means of respondent validation (Simmons, 2009), or member checking (Robson, 2002): the participants were asked to read their transcribed 
interviews and to comment on the research field notes as well as on drafts of the reported findings.

In the case of interviews, the difficulties in 'researching the powerful' (Walford, 2011) culminate in the asymmetry of power and status between the interviewer and the interviewee (see Ozga \& Gewirtz, 1994), creating challenges at each stage: gaining access, conducting relevant interviews and interpreting the data. However, it is possible to ask, as Walford (2012) does, whether, apart from the question of access, interviewing the powerful differs substantially from other types of research interview. In some cases access was facilitated through existing networks, however most interviewees were recruited only with the help of a letter of invitation. The aim in the letters was to level the asymmetries, and to provoke interest and trust by referring to the prestige of the institutions behind the research and showing an awareness of the recipients' earlier and current positions. Strategies aimed at 'diffusing authority' (Conti \& O'Neil, 2007) were used during the interviews: a senior interviewer (Ozga) was present in some of them and the rigorous preparation (Walford, 2011) included studying the documentation created by the interviewees and their background organisations.

The interviews are part of a larger research project comparing Finnish and English education policymaking, but the focus of the parts used in this article was specifically on the ways in which the academies' policy had changed the relationships between actors at the national and local levels, and how it had affected the steering capacity of central governance.

A thematic analysis of academy steering and evaluation was conducted on these two data sets for the purposes of this article. We carried out the analysis of the respective data individually. However, we share a common understanding of qualitative research as building a well-grounded interpretation, starting with describing and organising the text in the research material, selecting the relevant parts and eventually reorganising them into a holistic interpretation (Fairclough, 1992). Salokangas utilised a variety of data-reduction strategies to manage the cumulating data from the case academy, including summary sheets and memos that helped in identifying broad themes such as autonomy, innovation, pedagogy, management and, most importantly for this article, local-central relations. Kauko adopted similar strategies: he summarised the interview text in short statements, which he organised under broader recurring themes such as teacher professionalism, policy-making, data governance and the most relevant theme for this article, local-central relations. The interpretation and arguments used in this article derive mostly from the last theme, and also from searching all citations discussing academies. When we combined the analyses we encountered similar discussions in both data sets, such as the diminishing middle-tier governance, questions of accountability and transparency, and local autonomy. We encapsulated these issues in our analysis of steering and evaluation.

In the following we first discuss how disappointment in local authorities at the national level challenged their role as the main providers of education, and the ways in which this shifted control accordingly. In general, both major parties saw academies as a plausible new solution in this context. However, in terms of governance this challenging of local authorities seemed to create a power vacuum in the middle tier, which the case-study data makes apparent. Chain-specific managerial practices, 
curriculum pressures and the power of Ofsted were the main steering forces in the case academy. We report differences and contradictions in the local and national perspectives, and conclude by pondering on the extent to which local actors in academies still have space for action in the current model.

\section{Deregulated academies to counteract local-authority inefficiency}

Before going more deeply into the effects of evaluative practices, in this section we look into the reasons for the diminishing role of local authorities and how this created a political vacuum for the academies. It could be concluded from the existing literature and the interview material that dissatisfaction among national policymakers with local-level performance has developed gained momentum since the 1970s. The number of local authorities was reduced by a third in 1972 (Ozga, 1986), and the long period of Conservative rule since 1979 stripped them of many financial powers (Black, 2000). Finally, the Education Reform Act (1988) introduced changes in the steering powers of the state. First, these powers were centralised through the introduction of the National Curriculum and state-funded grant-maintained schools. Second, the 'local management of schools' scheme gave them increased control over their budgets. Third, the Act introduced new public management thinking through school choice and other market-driven practices. Other significant reforms of the era included the creation of the Office for Standards in Education (Ofsted) in 1992, which fortified the inspection regime, as well as the introduction of City Technology Colleges, the ancestors of the academies (Ball, 2013; Gewirtz, 2002).

The Labour governments (1997-2010) continued along the same lines, concentrating power to the centre and giving more autonomy to schools, although they also invested more financial resources in education (Exley \& Ball, 2011). Despite the increased funding, the tone of the message to local authorities was rather tough: the 'principle of zero tolerance will also apply to local education authorities' (Department of Education and Employment, 1997, p. 12; Framework Act, 1998, pp. 497A497B). The market emphasis was visible, for instance, in the White Paper indicating that 'an external private or voluntary sector sponsor' would 'take responsibility for a weak or failing school against a fixed-term contract' (Department for Education and Skills, 2001, p. 49), and the following Education Act (2002, pt. 4) made it possible to force 'weak' schools and local education authorities or those under 'special measures' to enter into such a contract.

One of the main political architects, Adonis (2012), described the academies as a solution to the failure of the comprehensive school, referring to the early academies that were beyond the control of the local authority and sponsored by non-profit organisations. However, the programme has undergone significant changes since then, many of them under the New Labour Government. The criteria regarding academy sponsorship have changed significantly, for example, as the government welcomed the involvement of universities and private schools, and later also local authorities (Balls, 2007; National Audit Office, 2010). The Coalition government (2010-2015) expanded the programme considerably. The Academies Act 2010 gave the Secretary of State power to transform maintained schools based on either the school's request or Ofsted inspection (Academies Act, 2010). Measures included 
forcing 'underperforming' schools to become academies, attracting Ofsted-ranked 'outstanding' schools to become academies with the help of incentives related to autonomy and extending the scheme to primary and special education. As a result, the number of academies has increased dramatically. Whereas the New Labour goal was to have 20 City Academies up and running before 2005 (Department for Education and Skills, 2001), at the beginning of 2012 the number was already 1,776, and the Secretary of Education (2010-2014) in the Coalition Government, Michael Gove, set a target to turn the 400 'worst-performing' primary schools into academies (Ball, 2013). In total the effect is remarkable. Many schools have distanced themselves from local-authority governance: as of August 2014, 4,009 academies were operational, of which 1,132 were associated with a sponsor (Department for Education, 2014).

The interview data reveal that national-level English politicians, with little partyrelated variation in emphasis, share the narrative regarding the failure of local authorities as providers of education. According to interviewees, the local authorities were stripped of their powers because of their poor performance, which forced central government to step in.

I $\quad[\mathrm{Y}]$ ou were saying about this development of the powers having shifted from the local level to the national level. So what do you see, why has this happened?

$\mathrm{R} \quad$ What happened [happened] because of poor standards. ... If you are a politician on the national level your mandate is national. You really cannot go back to the electorate and say I'm terribly sorry but [a name of a constituency] was to blame, not me. It just doesn't work like that. ... I think national politicians felt that if they were ever going to be able to deliver on their pledge to raise standards they would have to take control of it. (Politician, Labour)

Local authorities ... they should have been the ideal bodies to be accountable to deliver national policy. ... But there were failures in the quality of local authorities. ... [T] here were such grotesque failures on the part of some local authorities that something had to be done. (Politician, Conservative)

Another Labour politician described the sentiment inside the party before the academies programme was introduced thus: 'I understood and shared the Prime Minister's commitment that, if all else failed, why not have a special kind of school: an academy.'

From the perspective of the policymakers the academies appeared to resolve the main problem and dispute described by many politicians concerning how to raise achievement standards. The belief that the programme has succeeded in this at least partly is evident in some of the comments: 'That's people in all parties, feeling that the academies will provide a better route to be able to drive up standards' (Politician, other); 'I've no doubt, Michael Gove's and his colleagues', and I do talk to them a bit, belief is that this is how you raise standards' (Politician, other).

The interviewees referred to the academy programme as one of the key policies of the then Secretary of State. The Coalition government's criticism of local authorities was also understood as rather instrumental in promoting the programme:

All I'm saying [is that] they're quite happy with this kind of combination of general aggression towards local government alongside policy change in education undermining local. 
I don't sense that Michael Gove is actively trying to get local government out except insofar as the academies policy continues to be promoted. (Official)

Some politicians from the Labour and Conservative parties shared the narrative of cross-party support for the academies in that it was noted how the programme had survived different party regimes. However, other opinions were also expressed. Some interviewees talked of scepticism and downright opposition from the Labour left and some of the teachers' unions (Stakeholder; Politician, other), whereas at the local level the division was between local and national policymaking rather than along party-political lines (Politician, other; Stakeholder). Some interviewees also expressed grave concern about accountability (Stakeholder; Politican, Conservative) and how local authorities could take on the task of a democratically elected local government (Stakeholder).

Many interviewees understood that the academies and educational entrepreneurs, in other words the academy chains, were filling the vacuum left by the local authorities. One politician working at the local level suggested that the local authorities were losing power: 'The really influential people are the academy chains.' It was also noted that local authorities were operating in a highly competitive environment as schools deliberated on which provider would best suit their interests, especially their financial interests (Stakeholder). It appears from these interviews that there was some political momentum aimed at giving academies rather than local authorities the main responsibility for providing education in England.

In general, the dissolution of local control has brought the academies a lot of freedom. The notion of increased freedom in order to create conditions that would facilitate educational, managerial and governance-related innovation is the cornerstone of the sponsored academy movement (Adonis, 2012). In the following we take a closer look at how the academies are using these new freedoms and at the types of restriction they entail.

\section{Inspecting and evaluating academies}

Given the practical lack of restriction on academy schools among local authorities, apart from those that are acting as sponsors, national steering mechanisms and internal academy control are playing an ever more significant role in local governance. We focus on the way in which national policymakers understand the main opportunities and challenges involved in steering the academies and on the implications as far as schools are concerned.

Many policymakers argued that there needed to be some kind of middle tier. The basic concern was how the tasks of such a tier would be taken care of. One official presented the problem in terms of scale:

England is becoming unique amongst advanced industrial countries in not having a local or middle tier. It's very odd to run a whole school system, particularly primary schools ... from a single government department. (Official)

The resolution of this new situation was open to debate. Some envisaged a development allowing the academy chains to create their own middle layer of governance 
(Politician, Labour). An official who considered the current system unsustainable proposed the establishment of school commissions as a solution. Another thought the then Secretary of State had a 'view of different kinds of intermediate bodies', such as academy chains. Several newspapers referred in late 2013 to internal sources and documents at the Department for Education recommending the appointment of chancellors to supervise free schools and academies (The Guardian, 2013; The Telegraph, 2013). As the debate continues at the national level, at the local level the academies were implementing their own governance solutions.

At the local level the absence of a middle tier and the emergence of multi-academy sponsors have created a mosaic of a system. Indeed, the existing evidence indicates that sponsors running multi-academy chains take rather different approaches to the governance and management of the schools they run (Hill et al., 2012), some being more directly involved in academy-level decision-making than others. These academy-sponsor relationships may be dynamic in nature and vary greatly within the chains depending on the developmental stage of the academy (Salokangas \& Chapman, 2014). This was apparent in the case academy in that the local management and the sponsor embraced the independence to which academies are entitled by distancing themselves from the local authority. This is how one of its local governors, who was also a member of the city council, reflected on the dynamics between the academy, the sponsor and the local authority:

This particular academy - and maybe it's true with other academies in the chain as well - stress very much the independence of their model, rather than what I would like to see, independence within a strong mode of co-operation with other schools and local authorities. And this has led to the governance structure in which decisions are taken away from the LA. And to me it's a disappointment. This academy was the first one to be created [in the city] and learning from this we [local authority] have tried to make all the remaining academies much more strongly linked in to the city than this one is. And all the other sponsors have much stronger local links, either they are companies or institutions with city links. This academy was a bit isolated in relation to the city itself. (Local councillor)

The academy had indeed created distance from the local authority and instead of reaching out to the local schools was looking to the chain for collaboration and networks. This isolation was largely driven by the principal, and as the above citation suggests, did not necessarily reflect the views of other local stakeholders. This also points to a wider issue in local negotiations regarding the Local Authority's and the academy's attempts to respond to the shift to networked governance (Stoker, 2011; Ball \& Junemann, 2012).

The role of Ofsted in monitoring schools has become increasingly significant given the diminishing middle tier. In general, Ofsted was reported to have great support and trust among national policymakers. Given the lack of middle-tier democratic accountability, its importance was sometimes referred to as vital (Politician, Conservative). Reliance on Ofsted was also evident to a Labour politician, who perceived a general trend of assigning more and more tasks to it. However, one politician (other) expressed concern that at the local level 'there's a fear of inspections from Ofsted that only look at things that have gone wrong, they don't suggest solutions and don't help create solutions'. A stakeholder mentioned the problem that Ofsted did not have the 
right to investigate the head-office function in academy chains. After the research data had been collected it was reported in the press that this would change (The Guardian, 2014a). However, at the time of writing, the Secretary of State for Education, Nicky Morgan, opposed sponsor inspection (The Guardian, 2014b). In sum, trust in Ofsted was not as strong at the local level as it was among national policymakers.

Indeed, the paradox regarding the lack of sponsor accountability and the everincreasing accountability imposed upon schools (Glatter, 2012) was also prevalent in the academy-level data. In the following citation a teacher who had worked in two academies run by the same sponsor reflects on the impact of increased accountability on the teacher's work.

So the senior management observe us according to Ofsted criteria at least three times a year, sometimes more, I think that's a chain-wide policy. They are very strict about these observations, if you're not good or outstanding they are after your life- they make you do that. I hate observations. I don't mind people coming in and participating and helping, but actually sitting there and making notes is nerve-wracking, still after six years of teaching. And you know there's something about the architecture of these schools, windows everywhere. My old room was a mini room, in the middle of the Maths department, and it was windows all over, there were no walls, like a fish tank. I felt I'm always being watched. (Teacher)

The teachers provided fairly similar accounts of the strict observational practices carried out by senior management at the case academy. However, although the pressure of transparent practice was heavy on teachers, inter-organisational transparency did not similarly affect the sponsor in that the academy staff remained fairly oblivious to how the sponsor operated, and to which decisions were made locally at the academy and which were made at the sponsor level. As such the academy-level actors painted an image of a distant sponsor that was lacking in transparency as far as local stakeholders were concerned. This is how an experienced teacher responded to a question regarding her understanding of how the sponsor operated:

It's funny that you ask, I, and I think I can speak on behalf of also others working in this school, we know very little about how things are done and what is going on at the sponsor level. It's rather strange, and this may sound like I'm just complaining but it's very difficult to get answers to your questions from the headquarters, we don't really know who does what in that organisation, and there is a significant lack of clarity about important things like teachers' pay structure, and how appointments are made at the sponsor level and important things like that. (Teacher)

The documentary data collected at the sponsor level support this claim, as the chainlevel policy documents available to members of staff did not address either the staff pay structure or the appointment procedures. The scope of our research does not extend to estimations or comparisons of transparency between local-authority and sponsor governance. Moreover, these reflections stem from a single case study. However, this case brings to light issues that may arise at the local level as a result of a lack of sponsor transparency and the ever increasing demand for teacher accountability owing to the powerful role of Ofsted. National-level concerns about the missing accountable middle-tier system seemed to materialise at the academy. In addition, Ofsted's inspection criteria constituted powerful steering tools for the day-to-day 
practice in this context, which is indicative of the prevailing power of this type of steering on the one hand, and of the limited room for manoeuvre within such a framework on the other.

\section{Freedom from the curriculum?}

In addition to Ofsted, national-level curricula and assessment also play a major role in directing education. The academies are not obliged to follow the National Curriculum, however, which one stakeholder involved in academy sponsorship saw as a great opportunity, but also as a source of pressure to produce good results:

The potential is that it can be used for our benefit, because the academies can be run exactly as they want to be run, as long as they get the right results. And that's a big driver. But that means we could develop in our own schools, our own academies, the kind of curriculum that we really think is valuable for schools. (Stakeholder)

In principle academies are perceived to enjoy increased freedom, but many also recognise that there may be hidden problems in the implementation. Referring to all schools, one stakeholder wondered how it was possible for teachers and school leaders to keep producing good results in situations of change and turmoil. A politician (other) questioned why the Secretary of State was reforming the National Curriculum: 'Why is he [Michael Gove] bothering, if all the so-called best schools don't have to follow it?' The same stakeholder quoted above pondered on the same problem of increased freedom and the difficulties in implementing it in practice:

Strictly speaking the academy model gives more freedom to teach, to organise the school in a way which is in keeping with the foundation of the school. Now whether our schools will actually take that freedom I don't know. I don't think. Maybe in two years' time if we had the same conversation I could be saying different things. But, so we're at the beginning, I think, of a shift of mind-set. (Stakeholder)

Indeed, it became apparent at the local level that, regardless of the increased autonomy, the case academy followed the national curriculum across different subject areas. Teachers recognised the curricular autonomy associated with their academy status, but considered it theoretical owing to examination pressures. This is how the Curriculum Leader, whose role was to support all the academies across the chain in their curricular development, described the theoretical autonomy:

Although academies have the flexibility to do what they want, I think because we are still judged against performance tables with other schools, I don't think schools do as much as they could. ... [I]n year seven a lot of academies tend to do their own curriculum which tends to be based on project-based provision but on Key Stage 4 and Key Stage 5 I don't say they explore. This has also got to do with the nature of the chain, you know they [the sponsor] take on board failing schools, that's why they got to be able to perform rapid improvements and unfortunately they are measured on results, so to some extent the academies still [have] got to play the game. (Curriculum Leader)

Not surprisingly, the curricular freedom yields to the pressures of the testing regime. The lesson observations conducted in the academy confirmed this in that the learning experience in English and Maths for years 10 and 11 consisted of weekly exam 
preparation. From the perspective of an official such theoretical autonomy seemed to be a politically clever move, promoting freedom in principle while holding a grip on the steering mechanisms:

And he [Michael Gove] may say that that squares that circle for him. That he resets the curriculum in his own fashion. And essentially, the pressure, both informal and maybe some way through inspection and other mechanisms, through the examination system formally requires everyone to do it. (Official)

This resonates with the theoretical autonomy of the case academy, in which the national curriculum and exam preparation dominated the pedagogical practice, which again was evaluated by means of inspection according to Ofsted criteria.

\section{Conclusion}

This article reveals some interesting contrasts in national policy and local practice. The findings from a case study are not widely generalisable, and the views of the interviewees may provide a limited and subjective perspective. Nevertheless, our aim was not to paint a definitive picture, it was rather to point out arising discrepancies and existing complexities in central-local relations with regard to evaluation. Given the diminishing importance of legal and financial steering, as well as of local authorities, the soft power of evaluation remains the main element of national direction, and has a strong effect at the local level. The policymakers considered the school inspection regime the most important mechanism for ensuring accountability in schools operating beyond local-authority control. This resonated with the findings from the case academy: the inspections proved to have a significant influence on the day-today practice of teachers as well as of school management, in line with Dahler-Larsen's (2012) notion of constitutive effects on the relations of actors. The general academies-related policy discourse suggests that these schools are liberated from the National Curriculum, and the opportunities are both recognised and doubted in the policymakers' thoughts. However, the case academy rigorously followed the National Curriculum across subject areas to comply with national standardised testing.

Both national policymakers and local actors identified a blind spot in the steering, namely sponsor accountability. The national-level policymakers coined the term 'middle-tier problem', whereas at the school level there was a perceived lack of sponsor transparency. In the longer term this could be seen as a result of the diminishing role of local authorities. At the time of writing the discussion on the role of Ofsted in inspecting academy chains continues. Indeed, the role of Ofsted may become increasingly important, especially as the number of academies continues to increase.

Evaluation policy fits easily into the case academy's managerial practices. Drawing on earlier research, we suggest that this could indicate that the state intervention has been so strong that local-level path dependencies do not apply (Gains et al., 2005), or that at least in some localities evaluation has become an embedded policy (Ozga \& Jones, 2006). In conclusion, we consider both of these options.

Indeed, the state intervention has been very radical in introducing structural reforms. One of the biggest changes, the introduction of academies, has closely 
followed the NPM ideal in shifting responsibility away from the public sector, while retaining evaluative forms of state governance. Nevertheless, the organisation of academies at the local level, which seems to be in a constant state of reforming and building new relations, reflects the operational qualities of networked governance. Our results thus offer some possible new angles compared with earlier research on locallevel path dependency. Evaluation has stark implications on the local-level actor relations, and as such suggests constitutive effects (Dahler-Larsen, 2012), on the one hand, and on the other hand highlights the question of whether at the school level the organisation of local schooling matters in the presence of strong, national evaluation tools (Gains et al., 2005). This said, our research raises questions concerning continuity in local-level evaluation dynamics (see Kauko, 2013), regardless of the structural changes in schooling. Following this line of thinking, future analysis should concentrate more on action rather than structures.

At least in the case academy and for at least two reasons, it could be argued that evaluation has become an embedded practice giving less and less room to local actors. First, given the layers of governance and legislative reforms in the English education landscape, evaluation seems to be really efficient. Ofsted has strong support among policymakers, and has long historical legitimation. Testing, again, is the main measure defining school failure or success. However, it was unexpected how starkly polarised the changes have been in terms of governance levels, and in contrast with the results of our case study, how national visions of local innovation have been manifested in knee-jerk practices in reaction to inspection and testing. Second, confirming some earlier research findings (Bamfield, 2012; Exley \& Ball, 2011; Goodman \& Burton, 2012), in opposing the promotion of local-level freedom and innovation, the academy policy has strengthened managerial practices at the school and sponsor levels, and has enhanced national steering tools. As a result, autonomy associated with academies promotes managerial autonomy among schools and sponsors (Salokangas 2013), and national steering has strengthened its grip. We did not observe local embedded practices and cultures at the case academy that would challenge the central steering forces (cf. Tyack \& Cuban, 1995). On the contrary, actors at the local level adapted to the central command and followed the rules and expectations of Ofsted and standardised testing. However, it is worth noting that we scrutinised one academy in its local context and there may be deviations from this trend in other localities. Nevertheless, given that the findings from the case study and the interviews call into question some of the basic ideas put forward in earlier research on the significance of the local level, they point to the need for a larger-scale study focusing on what breathing space is left for local actors.

The question, which is uncomfortable politically and difficult to operationalise in research, concerns whether or not the academy policy has been successful. On the one hand, the case evidence provides little support on the extent to which the academies' legal freedoms have catalysed local innovation in pedagogical practices, for example. On the other hand, the academy policy has been very successful in changing the landscape of English schooling. All in all, the academies contribute to the constitution of a complex and marketised environment of public administration. The legalistic freedoms give more room for action in principle, and on paper result in a more fluid form of schooling. We found evidence that, despite their apparent free- 
dom, sponsored academies still closely follow national steering through evaluation. The long-term impact of the programme is still under construction, but we would not expect structural reforms catalysing pedagogical revolution as long as the local space for action is strongly restricted by tools of evaluation.

\section{Acknowledgements}

We would like to thank Jenny Ozga, Steven Courtney and James Duggan for providing helpful comments on an earlier version of the manuscript. We would also like to express our gratitude towards the Academy of Finland (Grant 257120) and the University of Manchester for financial support.

\section{References}

Academies Act (2010) The Academies Act 2010, No. 1937 (C. 102) (London, The Stationery Office). Adonis, A. (2012) Education, education, education. Reforming England's schools (London, Biteback).

Ainley, P. (2001) From a national system locally administered to a national system nationally administered: The new leviathan in education and training in England, fournal of Social Policy, 30(3), 457-476.

Altrichter, H., Heinrich, M. \& Soukup-Altrichter, K. (2014) School decentralization as a process of differentiation, hierarchization and selection, Fournal of Education Policy, 29(5), 675-699.

Andrews, R. \& Boyne, G. (2012) Structural change and public service performance: The impact of the reorganization process in English local government, Public Administration, 90(2), 297-312.

Ball, S. J. (2013) The education debate (Bristol, Policy Press).

Ball, S. J. \& Junemann, C. (2012) Networks, new governance and education (Bristol, Policy Press).

Balls, E. (2007) Department for Children Schools and Families - building on achievement, meeting new challenges, press notice, 10 July (Stockport, Wired Gov).

Bamfield, L. (2012) Setting schools free? Reflections on the freedom of autonomous schools, Philosophy of Education, 2012, 318-326.

Black, J. (2000) Modern British history since 1900 (Basingstoke, Hants, MacMillan).

Briault, E. W. H. (1976) A distributed system of educational administration: An international viewpoint, International Review of Education, 22 (4), 429-439.

British Educational Research Association (2004) Ethical guidelines for educational research (London, BERA).

Clarke, J. \& Newman, J. (1997) The managerial state (London, Sage).

Conti, J. A. \& O'Neil, M. (2007) Studying power: Qualitative methods and the global elite, Qualitative Research, 7(1), 63-82.

Dahler-Larsen, P. (2012) Constitutive effects as a social accomplishment. A qualitative of the political in testing, Educational Inquiry, 3(2), 171-186.

Department for Education (2010) The importance of teaching - the Schools White Paper (London, The Stationary Office).

Department for Education (2013a) Increasing the number of academies and free schools to create a better and more diverse school system. Available online at: https://www.gov.uk/government/ policies/increasing-the-number-of-academies-and-free-schools-to-create-a-better-and-morediverse-school-system (accessed 3 December 2014).

Department for Education (2013b) Primary academy magazine. Information for schools about converting to academy status (London, Department for Education).

Department for Education (2014) Open academies and academy projects in development. Available online at: https://www.gov.uk/government/publications/open-academies-and-academy-projects-in-development (accessed 17 February 2014). 
Department for Education and Skills (2001) Schools achieving success (Annesley, Notts, DfES Publications).

Department of Education and Employment (1997) Excellence in schools (London, The Stationery Office).

Education Act (2002) The Education Act 2002, chap. 32 (London, The Stationery Office).

Education Reform Act (1988) An Act to amend the law relating to education, 29th fuly 1988 (ch. 40) (London, Her Majesty's Stationery Office).

Evans, J. \& Penney, D. (1994) Whatever happened to good advice? Service and inspection after the Education Reform Act, British Educational Research fournal, 20(5), 519-533.

Exley, S. \& Ball, S. J. (2011) Something old, something new: Understanding Conservative education policy: The Conservative Party and social policy (Bristol, Policy Press), 97-118.

Fairclough, N. (1992) Discourse and social change (Cambridge, Polity Press).

Framework Act (1998) School Standards and Framework Act 1998 (ch. 31) (London, The Stationery Office).

Gains, F., John, P.C. \& Stoker, G. (2005) Path dependency and the reform of English local government, Public Administration, 83(1), 25-45.

Gewirtz, S. (2002) The managerial school (London, Routledge).

Glatter, R. (2012) Persistant preoccupations: The rise and rise of school autonomy and accountability in England, Educational Management Administration $\mathcal{E}$ Leadership, 40(5), 559-575.

Goodman, R. \& Burton, D. (2012) The Academies Programme: An education revolution?, Educational Futures, 4(3), 58-78.

Gorard, S. (2009) What are Academies the answer to?, fournal of Education Policy, 24(1), 101113.

Gorard, S. (2014) The link between Academies in England, pupil outcomes and local patterns of socio-economic segregation between schools, Research Papers in Education, 29(3), 268-284.

Grek, S., Lawn, M., Lingard, B. \& Varjo, J. (2009) North by northwest: Quality assurance and evaluation processes in European education, Fournal of Education Policy, 24(2), 121-133.

Gunter, H.M. \& McGinity, R. (2014) The politics of the Academies Programme: Natality and pluralism in education policy-making, Research Papers in Education, 29(3), 300-314.

Hatcher, R. (2011) The Conservative-Liberal Democrat coalition government's 'free schools' in England, Educational Review, 63(4), 485-503.

Hill, R., Dunford, J., Parish, N., Rea, S. \& Sandals, L. (2012) The growth of academy chains: Implications for leaders and leadership (Nottingham, National College for School Leadership).

Hood, C. \& Jackson, M. (1991) Administrative argument (Aldershot, Dartmouth Publishing).

Jarl, M., Fredriksson, A. \& Persson, S. (2012) New public management in public education: A catalyst for the professionalization of Swedish school principals, Public Administration, 90(2), 429444.

Kauko, J. (2013) Dynamics in higher education politics: A theoretical model, Higher Education, 65 (2), 193-206.

Kellaghan, T., Stufflebeam, D. \& Wingate, L. (2003) Introduction, in: T. Kellaghan \& D. Stufflebeam (Eds) International handbook of educational evaluation (Dordrecht, Kluwer Academic), $1-6$.

Kelly, J. (2007) Reforming public services in the UK: Bringing in the third sector, Public Administration, 85(4), 1003-1022.

Lawn, M. (2013) A systemless system: Designing the disarticulation of English state education, European Educational Research fournal, 12(2), 231-241.

Lundgren, U. P. (1991) Educational policymaking, decentralization and evaluation, in: M. Granheim, M. Kogan, U. P. Lundgren (Eds) Evaluation as policymaking. Introducing evaluation into a national decentralized educational system (London, Jessica Kingsley), 23-42.

Maroy, C. \& Van Zanten, A. (2009) Regulation and competition among schools in six European localities, Sociologie du Travail, 51(1), e67-e79.

McGinity, R. \& Salokangas, M. (2014) Introduction: 'Embedded research' as an approach into academia for emerging researchers, Management in Education, 28(1), 3-5. 
National Audit Office (2010) The Academies Programme: Report by the Comptroller and auditor General, published 10 September 2012 (London, The Stationery Office).

Olmedo, A. (2014) From England with love ... ARK, heterarchies and global 'philantropic governance', fournal of Education Policy, 29(5), 575-597.

Osborne, D. \& Gaebler, T. (1993) Reinventing government: How the entrepreneurial spirit is transforming the public sector (Reading MA, Addison-Wesley).

Ozga, J. (1986) The policy-makers, Module 2: Introducing education policy: principles and perspectives. E333 Policy-Making in Education (Milton Keynes, The Open University), 35-85.

Ozga, J. \& Gewirtz, S. (1994) Sex, lies and audiotape: Interviewing the education policy elite, Researching Education Policy: Ethical and Methodological Issues (London, Falmer), 121-138.

Ozga, J. \& Jones, R. (2006) Travelling and embedded policy: The case of knowledge transfer, fournal of Education Policy, 21(1), 1-17.

Pierson, P. (2000) Increasing returns, path dependence, and the study of politics, The American Political Science Review, 94(2), 251-267.

Pollitt, C. (2009) Bureaucracies remember, post-bureaucratic organisations forget?, Public Administration, 87(2), 198-218.

Robson, C. (2002) Real world research - a resource for social scientists and practitioner-researchers (Oxford, Blackwell Publishing).

Salokangas, M. (2013) Autonomy and innovation in English academy schools: A case study (Manchester, University of Manchester, School of Education).

Salokangas, M. \& Chapman, C. (2014) Exploring governance in two chains of academy schools. A comparative case study, Educational Management Administration $\mathcal{E}$ Leadership, 42(3), 372-386.

Simmons, H. (2009) Case study research in practice (London, Sage).

Simola, H., Rinne, R., Varjo, J. \& Kauko, J. (2013) The paradox of the education race: How to win the ranking game by sailing to headwind, Fournal of Education Policy, 28(5), 612-633.

Söderström, M. \& Uusitalo, R. (2010) School choice and segregation: Evidence from an admission reform, The Scandinavian fournal of Economics, 112(1), 55-79.

Stoker, G. (2011) Was local governance such a good idea? A global comparative perspective, Public Administration, 89(1), 15-31.

The Guardian (2013) Michael Gove to appoint new regulators to oversee free schools and academies. Available online at: http://www.theguardian.com/politics/2013/nov/20/michael-gove-regulators-free-schools (accessed 18 February 2014).

The Guardian (2014a) Education in brief: Ofsted has started inspecting academy chains. Available online at: http://www.theguardian.com/education/2014/feb/11/ofsted-begins-inspections-academy-chains (accessed 13 March 2014).

The Guardian (2014b) Education secretary in row with MPs over academy schools inspections. Available online at: http://www.theguardian.com/education/2014/oct/15/education-secretary-row-mpsacademy-schools-inspections (accessed 16 October 2014).

The Telegraph (2013) New 'chancellors' to oversee free schools and academies. Available online at: http://www.telegraph.co.uk/education/10464140/New-chancellors-to-oversee-free-schoolsand-academies.html (accessed 18 February 2014).

Tomlinson, S. (2001) Education in a post-welfare society (Buckingham, Open University Press).

Tyack, D. \& Cuban, L. (1995) Tinkering toward utopia. A century of public school reform (Cambridge, MA, Harvard University Press).

Walford, G. G. (1987) Research role conflicts and compromises in public schools, Doing sociology of education (Lewes, The Falmer Press), 45-66.

Walford, G. G. (2011) Researching the powerful, British Educational Research Association on-line resource. Available online at: https://www.bera.ac.uk/wp-content/uploads/2014/03/Researchingthe-Powerful.pdf (accessed 9 September 2014).

Walford, G. G. (2012) Researching the powerful in education: A re-assesment of the problems, International fournal of Research $\mathcal{E}$ Method in Education, 35(2), 111-118.

Woods, G. J. \& Woods, A. P. (2009) Day of dialogue: Research priorities from the Researching Academies Conference, Management in Education, 23(3), 96-99. 